\title{
UPAYA PENINGKATAN MOTIVASI DAN PRESTASI BELAJAR SISWA MELALUI METODE EKSPERIMEN PADA PELAJARAN KIMIA
}

\author{
Ni Luh Nyoman Suwidyastuti Agustini \\ SMK Negeri 2 Negara \\ e-mail: nyomanswidyastutui@gmail.com
}

\begin{abstract}
Abstrak
Penelitian ini bertujuan untuk mengetahui peningkatan motivasi dan prestasi belajar peserta didik melalui metode eksperimen pada pelajaran kimia pada siswa kelas $X$ Teknik Otomotif 4 di SMK Negeri 2 Negara yang terdiri atas 2 siklus yaitu siklus I dan siklus II. Subyek penelitian berjumlah 25 orang dan obyek penelitian adalah motivasi dan prestasi belajar. Instrumen yang digunakan berupa kuesioner untuk mengukur motivasi belajar peserta didik dan tes hasil belajar untuk mengukur prestasi belajar selama siklus I dan II. Data yang dikumpulkan berupa data kuantitatif dan kualitatif. Metode analisis datanya adalah deskriptif baik untuk data kuantitatif maupun data kualitatif. Hasil penelitian menunjukkan bahwa data refleksi awal rata-rata prestasi belajar dan ketuntasan klasikal relatif rendah, namun setelah dilaksanakan siklus I hasilnya meningkat dengan prestasi belajar mencapai rata-rata 70.56 dan ketuntasan belajar mencapai $64.00 \%$ serta hasil observasi terhadap motivasi belajar siswa mencapai ratarata 74.72. Setelah dilaksanakan siklus II secara keseluruhan terdapat peningkatan ratarata sebesar 22.56 dan ketuntasan meningkat $72.00 \%$ dari hasil refleksi awal. Sedangkan motivasi belajar secara keseluruhan terdapat peningkatan 27.40 dari motivasi hasil refleksi awal. Dari uraian di atas, dapat disimpulkan bahwa penerapan metode eksperimen pada pelajaran kimia dapat meningkatkan secara signifikan motivasi dan prestasi belajar siswa kelas X Teknik Otomotif 4 di SMK Negeri 2 Negara pada semester genap tahun ajaran 2018/2019.
\end{abstract}

Kata-kata kunci : Motivasi, Prestasi Belajar, dan Metode Eksperimen

\begin{abstract}
This study aims to determine the increase in motivation and learning achievement of students through the experimental method in chemistry lessons in tenth grade Automotive Engineering four students at SMK Negeri 2 Negara consisting of two cycles, namely cycle I and cycle II. 25 research subjects and the object of research was motivation and learning achievement. $r$. The instrument used in the form of a questionnaire to measure students' learning motivation and learning outcomes tests to measure learning achievement during cycles I and II. Data collected in the form of quantitative and qualitative data. The data analysis method is descriptive for both quantitative and qualitative data. The results showed that the initial reflection data on average learning achievement and classical completeness were relatively low, but after the first cycle was implemented the results improved with learning achievements reaching an average of 70.56 and learning completeness reaching $64.00 \%$ and the results of observations on student learning motivation reached an average 74.72 . After carrying out the second cycle there was completion of learning in the second cycle reached $92.00 \%$, this means there was an increase of $28.00 \%$ from the first cycle. overall there was an average increase of 22.56 and completeness increased $72.00 \%$ from the results of the initial reflection. While learning motivation is overall there is an increase of 27.40 from the motivation of the initial reflection. From the description above, it can be concluded that the application of the experimental method in chemistry lessons can significantly increase the motivation and learning achievement of students of tenth grade Automotive Engineering 4 at SMK Negeri 2 Negara in semester genap 2018/2019 academic year.
\end{abstract}

Keywords: Motivation, Learning Achievement, and Experimentation Methods 


\section{Pendahuluan}

Pendidikan memegang peranan yang sangat penting dalam proses peningkatan kualitas sumber daya manusia. Kualitas sumber daya manusia menyangkut kemampuan manusia baik secara individual maupun secara kolektif untuk bertahan hidup di tengah tuntutan kebutuhan dan ancaman persaingan dari individu dan komunitas manusia lainnya. Pendidikan adalah usaha sadar dan terencana untuk mewujudkan suasana belajar dan proses pembelajaran agar peserta didik secara aktif mengembangkan potensi dirinya untuk memiliki kekuatan spiritual keagamaan, pengendalian diri, kepribadian, kecerdasan, akhlak mulia, serta keterampilan yang diperlukan dirinya, masyarakat, bangsa, dan negara. Fungsi pendidikan mengembangkan kemampuan dan membentuk watak serta peradaban bangsa, bertujuan mencerdaskan kehidupan bangsa, bertujuan untuk berkembangnya potensi peserta didik agar menjadi manusia yang beriman dan bertaqwa kepada Tuhan Yang Maha Esa, berakhlak mulia, sehat, berilmu cakap, kreatif, mandiri, dan menjadi warga negara yang demokratis serta bertanggung jawab. Untuk mewujudkan tujuan tersebut, perlu adanya peningkatan kualitas dan mutu pembelajaran.

Proses pembelajaran merupakan suatu sistem yang kompleks dan unik, karena melibatkan banyak komponen seperti siswa, guru, kurikulum, fasilitas penunjang, lingkungan belajar dan lain sebagainya yang saling terkait. Dalam mengelola proses pembelajaran yang kompleks dan unik tersebut, guru mempunyai peran yang sangat strategis dan sentral. Guru dituntut untuk mampu melaksanakan multi peran yang dilandasi kompetensi personal, profesional, dan sosial yang padu dan mantap. Guru sebagai pembelajar memiliki kewajiban mencari, menemukan, dan diharapkan dapat memecahkan masalah-masalah belajar siswa (Dimyati dan Mudjiono, 2006: 260). Dikatakan pula bahwa dalam pencarian dan penemuan masalah-masalah tersebut guru dapat melakukan langkah-langkah berupa (i) pengamatan perilaku belajar, (ii) analisis hasil belajar, dan (iii) melakukan tes hasil belajar. Dengan langkahlangkah tersebut guru memperoleh peluang menghimpun data siswa berkenaan dengan proses belajar dan hasil belajar.

Menurut Joseph Mbulu (2001: 58), metode eksperimen adalah cara penyajian bahan pelajaran dimana siswa melakukan eksperimen, siswa diberi pengalaman untuk mengalami sendiri tantangan suatu objek, menganalisis, membuktikan, dan menarik kesimpulan tentang suatu objek keadaan. Dengan demikian siswa dituntut untuk mengalami sendiri, mencari suatu kebenaran, mencari suatu data baru yang diperlukannya, mengolah sendiri, membuktikan suatu dalil atau hukum yang menarik kesimpulan atas proses yang dialaminya itu. Penggunaan teknik ini mempunyai tujuan agar siswa mampu mencari dan menemukan sendiri berbagai jawaban atau persoalan-persoalan yang dihadapinya dengan mengadakan percobaan sendiri. Melatih siswa untuk berpikir yang ilmiah (scientific thinking). Dengan eksperimen siswa menemukan bukti kebenaran dari sesuatu yang sedang dipelajarinya. Apabila seseorang mencoba sesuatu yang belum diketahui hasilnya maka ia melakukan suatu eksperimen. Kualitas hasil suatu produksi dapat diselidiki dengan melakukan suatu eksperimen. Guru dapat menugaskan muridmurid untuk melakukan eksperimen sederhana, baik di dalam kelas maupun di luar kelas. Untuk memudahkan pemahaman konsep-konsep teoritis yang disajikan guru, guru hendaknya menugaskan murid-murid untuk melakukan eksperimen. Sebuah eksperimen dapat dilakukan oleh murid-murid untuk menguji hipotesis suatu masalah dan kemudian menarik kesimpulan.

Para penganut konstruktivisme, seperti Shymansky dan Kely (dalam Trianto, 2007) mendefinisikan belajar sebagai pengkontruksian pengetahuan oleh individu-individu sebagai pemberian makna atas data sensorik dalam hubungannya dengan pengetahuan sebelumnya. Belajar sebagai pembentukan makna secara aktif oleh pebelajar dengan menggunakan pengetahuan yang telah dimiliki sebelumnya dan masukan-masukan sensori baru, serta pembuatan hubungan-hubungan dalam pembentukan makna. Pembelajar sendiri yang membuat penalaran atas apa yang dipelajarinya dengan cara mencari makna, membandingkannya dengan apa yang telah ia ketahui serta menyelesaikan ketegangan (konflik) antara apa yang ia ketahui dengan pengalaman baru.

Dari definisi tersebut di atas tidak ada kontradiksi makna bahkan saling melengkapi. Dengan demikian, dapat dirumuskan bahwa prestasi belajar merupakan kemampuan aktual 
yang dapat diukur dan berwujud penguasaan ilmu pengetahuan, sikap, keterampilan, dan nilainilai yang dicapai oleh siswa dari hasil proses belajar di sekolah. Hasil belajar yang diperoleh siswa dalam suatu mata pelajaran dinyatakan dalam bentuk nilai yang disebut dengan prestasi belajar.

Pentingnya usaha untuk meningkatkan motivasi dan prestasi belajar siswa, diperlukan pembelajaran yang dapat membantu guru dalam mengaitkan materi pelajaran dengan situasi dunia nyata siswa dan mendorong siswa dalam membuat relasi antara pengetahuan yang dimiliki dengan implementasinya dalam kehidupan sehari-hari. Faktor lingkungan belajar, minat belajar, sebagai kreativitas penemuan siswa secara tidak langsung akan berkaitan dengan proses pertumbuhan mental ke arah yang lebih maju. Menurut Padmanaba (2018) media pembelajaran dapat meningkatkan motivasi siswa dalam belajar.

Motivasi dan prestasi belajar siswa juga dipengaruhi oleh metode pembelajaran yang digunakan oleh guru. Berdasarkan hasil observasi dan tes dalam pembelajaran kimia dengan menggunakan motode pembelajaran yang konvensional yaitu metode pembelajaran yang masih mengutamakan ceramah, pembelajaran yang masih didominasi oleh guru (teachercentrered), dan kurang memberikan akses bagi siswa untuk berkembang secara sendiri, masih ditemukan kendala yang dialami saat pelaksanaan pembelajaran. Hal ini dapat dilihat dari persentase aktivitas dan motivasi belajar siswa yang diperoleh dengan metode pembelajaran yang konvensional masih rendah.

Motivasi memiliki fungsi yang penting dalam pembelajaran. Fungsi motivasi adalah mendorong timbulnya tingkah laku atau perbuatan, sebagai pengarah untuk mencapai tujuan yang diinginkan, dan sebagai penggerak tingkah laku. Dengan kata lain, motivasi adalah usaha untuk menyediakan kondisi tertentu sehingga seseorang ingin melakukan sesuatu sesuai dengan tujuan yang diharapkan (A.M., Sardiman, , 2003). Jika dikaitkan dengan prestasi belajar, maka sudah tentu motivasi dan prestasi belajar memiliki keterkaitan yang erat. Untuk memperoleh tujuan yang diinginkan yaitu kepuasan dalam penguasaan prilaku khususnya prestasi, seseorang tentu harus mendorong atau memotivasi dirinya untuk berbuat yang positif sehingga berhasil mencapai tujuan yang diinginkannya. Hal itu menunjukkan bahwa antara motivasi dan prestasi memiliki keterkaitan yang konkret, yaitu untuk memperoleh prestasi yang baik, tentu seseorang harus memiliki motivasi yang baik pula. Prestasi belajar tidak hanya ditentukan oleh peringkat kelas dan perangkat lunak, tetapi juga oleh motivasi untuk belajar. Motivasi belajar merupakan keseluruhan daya penggerak di dalam diri siswa yang menimbulkan kegiatan belajar, menjamin kelangsungan dari kegiatan belajar, dan memberi arah pada kegiatan belajar, sehingga tujuan yang dikehendaki oleh subyek belajar itu dapat tercapai).

Motivasi intrinsik merupakan pendorong dalam belajar setiap siswa. Sedangkan motivasi ekstrinsik merupakan pendorong pelengkap dari luar siswa dalam belajar. Motivasi untuk belajar adalah penting dalam melakukan kegiatan belajar, sebab seseorang yang tidak mempunyai motivasi dalam belajar, tidak akan mungkin melakukan aktivitas belajar. Hal ini merupakan suatu pertanda, bahwa sesuatu yang akan dikerjakan itu tidak menyentuh kebutuhannya. Segala sesuatu yang menarik minat orang tertentu selama sesuatu itu tidak berkaitan dengan kebutuhannya. Oleh karena itu apa yang dilihat seseorang tentu akan membangkitkan minatnya sejauh yang dilihatnya itu mempunyai hubungan dengan kepentingan pribadi. Jadi yang dimaksud dengan motivasi belajar adalah keseluruhan daya penggerak baik ekstrinsik maupun intrinsik dalam diri siswa yang menimbulkan, yang menjamin kelangsungan, dan memberikan arah pada kegiatan belajar, sehingga tujuan belajar yang dikehendaki siswa tercapai.

Belajar pada hakekatnya adalah perubahan dalam diri seseorang yang disebabkan oleh adanya interaksi dengan lingkungannya. Perubahan yang dimaksud adalah perubahan dalam bidang keterampilan, kebiasaan, sikap, dan pengertian atau aspirasi. Yang jelas seseorang yang mengalami perubahan-perubahan tersebut maka ia tidak seperti keadaan sebelumnya. Untuk memperoleh perubahan perilaku itu maka diperlukan latihan atau pengalaman yang berupa ilmu pengetahuan, keterampilan, dan sikap. Oleh karena, itu perlu diingat bahwa belajar adalah peristiwa yang terjadi secara sadar artinya seseorang yang terlibat dalam peristiwa itu yang pada akhirnya menyadari bahwa ia telah mempelajari sesuatu. Dengan mengkaji hal 
tersebut di atas, maka faktor-faktor yang dapat mempengaruhi hasil belajar antara lain: (1) faktor yang ada pada diri organisme itu sendiri yang dapat disebut faktor individual, seperti kematangan/pertumbuhan, kecerdasan, latihan, motivasi, dan faktor pribadi, (2) faktor yang ada diluar individu yang disebut faktor sosial, seperti faktor keluarga/keadaan rumah tangga, guru dan cara mengajarnya, alat-alat yang dipergunakan dalam belajar mengajar, lingkungan dan kesempatan yang tersedia serta motivasi sosial. Dalam penelitian ini faktor yang dari luar seperti guru dan cara mengajarnya yang akan menentukan hasil belajar siswa. Cara mengajarnya itu merupakan faktor kebiasaan guru itu atau pembawaan guru itu dalam memberikan pelajaran. Juga dikatakan oleh Slameto (2003) bahwa faktor-faktor yang mempengaruhi belajar banyak jenisnya tetapi dapat digolongkan menjadi dua golongan saja yaitu faktor intern dan faktor ekstern. Faktor intern diklasifikasi menjadi tiga faktor yaitu faktor jasmaniah, faktor psikologis, dan faktor kelelahan. Faktor jasmaniah antara lain kesehatan dan cacat tubuh. Faktor psikologis antara lain intelegensi, perhatian, minat, bakat, motif, kematangan, dan kesiapan. Faktor kelelahan antara lain kelelahan jasmani dan rohani. Sedangkan faktor ekstern digolongkan menjadi tiga faktor yaitu faktor keluarga, faktor sekolah, dan faktor masyarakat. Faktor keluarga antara lain cara orang tua mendidik, relasi antara keluarga, suasana rumah tangga, dan keadaan ekonomi keluarga. Faktor sekolah antara lain metode mengajar, kurikulum, relasi guru dengan siswa, relasi siswa dengan siswa, disiplin sekolah, pelajaran dan waktu sekolah, standar pelajaran, keadaan gedung, metode belajar, dan tugas rumah. Faktor masyarakat antara lain kegiatan siswa dalam masyarakat, mas media, teman bergaul, dan bentuk kehidupan masyarakat. Peningkatan hasil belajar yang penulis teliti dalam hal ini dipengaruhi oleh faktor ekstern yaitu metode mengajar guru. Selain hal-hal di atas ada pula faktor-faktor lain yang mempengaruhi belajar siswa. Faktor-faktor tersebut dapat digolongkan menjadi dua faktor yaitu faktor internal (yang berasal dari dalam diri) dan faktor eksternal (yang berasal dari luar diri). Faktor internal termasuk kesehatan, intelegensi dan bakat, minat dan motivasi, serta cara belajar. Sedangan faktor ekstemal termasuk keluarga, sekolah, masyarakat, dan lingkungan sekitar.

Dari sudut si pembelajar (siswa) berhasil atau tidaknya seseorang dalam belajar dipengaruhi oleh kondisi kesehatan jasmani siswa, kecerdasan, bakat, minat dan motivasi, penyesuaian diri, dan kemampuan berinteraksi siswa. Sedangkan yang bersumber dari proses belajar, maka kemampuan guru dalam mengelola proses pembelajaran sangat menentukan hasil belajar siswa. Guru yang menguasai materi pelajaran dengan baik, menggunakan metode dan media pembelajaran yang tepat mampu mengelola kelas dengan baik akan memberi pengaruh yang positif terhadap hasil belajar siswa.

Dalam proses belajar mengajar biasanya banyak ditemukan kesulitan-kesulitan diantaranya siswa kurang termotivasi. Aktivitas cenderung rendah yang pada akhirnya berdampak pada rendahnya hasil belajar. Berangkat dari kelemahan tersebut maka peran guru sangat penting dalam mengkemas pembelajaran sehingga siswa mampu berperan aktif dalam proses pembelajaran sehingga tercapai suatu tujuan pembelajaran.

Keberhasilan proses pembelajaran dapat ditunjukkan dengan tercapainya tujuan pembelajaran atau indikator-indikator dari kompetensi dasar yang telah ditetapkan. Keberhasilan dalam penelitian ini ditunjukan dengan adanya peningkatan motivasi belajar baik secara individual maupun secara kolektif (kelompok) dan ditunjukan dengan adanya pencapaian nilai hasil belajar di atas standar KKM.

Berdasarkan uraian tersebut, dapat disusun kerangka berpikir yaitu untuk meningkatkan motivasi dan prestasi belajar siswa pada pelajaran kimia dapat dilaksanakan melalui metode eksperimen.

Berdasarkan studi awal tentang rendahnya motivasi dan prestasi belajar siswa pada pelajaran kimia, mungkin disebabkan oleh beberapa faktor antara lain: 1) Metode dan strategi pembelajaran yang digunakan mungkin kurang menantang, memotivasi, dan menyenangkan, 2) Sarana dan media pembelajaran masih kurang, 3) Motivasi belajar siswa dalam proses pembelajaran sangat rendah, dan 4) Kemampuan dasar dan daya ingat siswa sangat beraneka ragam dan relatif rendah.

Dari permasalahan dan pendapat di atas maka penulis mencoba memberikan suatu alternatif untuk mengatasi masalah tersebut, yaitu dengan menerapkan metode pembelajaran eksperimen yang bertujuan untuk meningkatkan motivasi dan prestasi belajar siswa. Dalam 
proses belajar mengajar dengan metode eksperimen ini siswa diberi kesempatan untuk mengalami sendiri atau melakukan sendiri, mengikuti suatu proses, mengamati suatu objek, menganalisis, membuktikan, dan menarik kesimpulan sendiri mengenai suatu objek, keadaan atau proses sesuatu. Dengan demikian siswa dituntut untuk mengalami sendiri, mencari kebenaran atau mencoba mencari suatu hukum atau dalil, dan menarik kesimpulan atau proses yang dialaminya itu. Selain itu keunggulan metode pembelajaran eksperimen antara lain membuat siswa lebih percaya atas kebenaran atau kesimpulan berdasarkan percobaannya, dapat membina siswa untuk membuat terobosan-terobosan baru dengan penemuan dari hasil percobaannya dan bermanfaat bagi kehidupan manusia, serta hasil-hasil percobaan yang berharga dapat dimanfaatkan untuk kemakmuran umat manusia. Sehubungan dengan itu penulis mencoba mengangkat sebuah judul "Upaya Peningkatan Motivasi dan Prestasi Belajar Siswa Melalui Metode Eksperimen pada Pelajaran Kimia Siswa Kelas X Teknik Otomotif 4 di SMK Negeri 2 Negara Tahun Pelajaran 2018/2019"

\section{Metode}

Penelitian ini adalah penelitian tindakan kelas (PTK), yaitu penelitian tindakan yang bertujuan untuk mengembangkan keterampilan-keterampilan, metode atau pendekatan baru untuk memecahkan masalah dengan penerapan langsung melalui tindakan teretensi. Menurut Suharjono (2008: 58), penelitian tindakan kelas (PTK) adalah penelitian tindakan (action research) yang dilakukan dengan tujuan memperbaiki mutu praktek pembelajaran di kelasnya. PTK berfokus pada kelas atau pada proses belajar mengajar, bukan pada input kelas (silabus, materi, dan lain-lain) ataupun output (hasil belajar). Sedangkan menurut Hopkins (2011), Penelitian Tindakan Kelas yaitu tindakan yang dilakukan oleh guru untuk meningkatkan dirinya atau teman sejawatnya untuk menguji asumsi teori pendidikan di dalam praktek, atau mempunyai makna sebagai evaluasi dan implementasi keseluruhan prioritas sekolah.

Teknik atau metode yang digunakan dalam pengumpulan data penelitian sesuai dengan instrumen penelitian. Bila metode pengumpulan data yang dipilih metode wawancara maka instrumen penilaiannya adalah pedoman wawancara, bila metode pengumpulan data yang dipilih metode observasi maka instrumen penilaiannya adalah lembar observasi, bila metode pengumpulan data yang dipilih metode angket maka instrumen penilaiannya adalah angket, bila metode pengumpulan data yang dipilih metode dokumentasi maka instrumen penilaiannya adalah pedoman dokumentasi, bila metode pengumpulan data yang dipilih metode tes maka instrumen penilaiannya adalah tes ( Suharsimi Arikunto, 2004).

Dari pendapat tersebut di atas maka dalam penelitian ini digunakan metode pengumpulan data yaitu sebagai berikut :

Teknik pengukuran adalah cara untuk mengumpulkan data penelitian yang bersifat kuantitatif atau menghasilkan angka-angka. Alat pengukuran yang digunakan berupa tes tertulis dengan berbagai macam bentuk dan skala pengukurannya. (Dwi Agus Sudjimat, 2004: 69). Tes sebagai instrument pengumpulan data adalah serangkaian pertanyaan atau latihan yang digunakan untuk mengukur keterampilan pengetahuan, intelegensi, kemampuan atau bakat yang dimiliki oleh individu atau kelompok.

Untuk mengetahui prestasi belajar siswa, pada akhir siklus setiap siswa diberikan tes hasil belajar atau tes prestasi belajar. Tes prestasi (achievement test) adalah tes yang digunakan untuk mengukur pencapaian siswa setelah mengikuti pembelajaran. Bentuk tes yang digunakan adalah dalam bentuk tes uraian singkat. Materi tes memuat tentang kompetensi dasar Pengujian pH Larutan Asam Basa dengan Menggunakan Indikator. Hasil tes digunakan sebagai data primer, diolah, dan dianalisa untuk mendapatkan suatu kesimpulan hasil belajar siswa.

Kuesioner merupakan suatu teknis pengumpulan data dengan memberikan atau menyebarkan daftar pertanyaan kepada responden dengan harapan memberikan respon atas daftar pertanyaan tersebut. Daftar pertanyaan dapat bersifat terbuka, yaitu jika jawaban tidak ditentukan sebelumnya oleh peneliti dan dapat bersifat tertutup, yaitu alternatif jawaban telah ditentukan sebelumnya oleh peneliti (Juliansyah Noor, 2011: 139). 
Adapun instrumen daftar pertanyaan dapat berupa pertanyaan (berupa isian yang akan diisi oleh responden), checklist (berupa pilihan dengan cara memberi tanda pada kolom yang disediakan), dan skala (berupa pilihan dengan memberi tanda pada kolom berdasarkan tingkatan tertentu).

Metode observasi merupakan cara yang sangat baik untuk mengamati tingkah laku manusia yang dapat dilihat dengan mata, yaitu tingkah laku manusia dalam ruang, waktu, dan keadaan tertentu. (Suharsini Arikunto, 2004: 88). Untuk mengamati prilaku siswa dalam mengikuti pelajaran, peneliti menggunakan metode observasi untuk mendapatkan data-data yang berkenaan dengan motivasi belajar siswa selama proses belajar berlangsung. Alat yang digunakan adalah berupa lembar observasi. Hasil observasi dalam penelitian ini hanya digunakan sebagai data sekunder yaitu untuk mengetahui tingkat motivasi belajar siswa.

Data yang telah terkumpul dari hasil tes dan observasi dianalisis dengan menggunakan analisis deskriptif yang berlangsung setiap akhir siklus, yaitu : a) Hasil belajar dianalisis dengan analisis diskriptif komparatif yaitu membandingkan nilai tes antar siklus maupun dengan indikator kinerja, dan b) Observasi dengan analisis deskriptif berdasarkan hasil observasi dan refleksi.

Untuk menilai pemahaman dan penerapan konsep dari hasil tes akan dicari nilai rata-rata dan daya serap siswa secara klasikal. Untuk menentukan tingkat motivasi belajar siswa dilakukan dengan membandingkan nilai rata-rata motivasi belajar siswa dengan menggunakan lima kriteria model PAP. Berdasarkan teori ini, lima kriteria dimaksud adalah sebagai berikut :

Tabel 1. Lima Kriteria PAP

\begin{tabular}{ll}
\hline Rata-Rata & Tingkat Motivasi \\
\hline $90-100$ & Sangat tinggi \\
$80-89$ & Tinggi \\
$65-79$ & Cukup \\
$55-64$ & Rendah \\
$0-54$ & Sangat Rendah \\
\hline
\end{tabular}

\section{Hasil dan Pembahasan}

Adapun kondisi SMK Negeri 2 Negara adalah salah satu sekolah menengah kejuruan yang ada di Kabupaten Jembrana yang memiliki 5 jurusan yaitu pertanian, peternakan, kelautan, teknik pengolahan hasil perikanan, dan teknik otomotif. Dan masing-masing jurusan memiliki beberapa rombongan belajar (rombel) atau kelas.

Adapun kondisi SMK Negeri 2 Negara memiliki siswa dengan motivasi rendah belajar ilmu kimia, akibatnya hasil belajar yang ditunjukkan siswa sangatlah rendah. Hal ini merupakan masalah yang harus disikapi terutama oleh guru mata pelajaran untuk meningkatkan prestasi belajar siswa.

Berdasarkan data hasil refleksi awal setelah dilakukan ulangan harian pertama mata pelajaran kimia khususnya di kelas $X$ Teknik Otomotif 4 , nilai prestasi belajar siswa hanya mencapai rata-rata 58.24, masih relatif rendah bila dibandingkan dengan kriteria ketuntasan minimum (KKM) yaitu 70.00 (Standar Nasional). Hal ini sangat diperlukan adanya upaya meningkatkan sehingga siswa mampu mencapai standar ideal atau standar ketuntasan minimum. Sedangkan daya serap baru mencapai $58.24 \%$ masih dibawah $75.00 \%$. Kesenjangan nilai dari hasil ulangan harian terhadap kriteria ketuntasan minimum (70.00 58.24) adalah 11.76 ini harus diupayakan penuntasan, minimal $90.00 \%$ siswa mencapai hasil di atas KKM, ketuntasan belajar baru mencapai $20.00 \%$ ini berarti masih sangat rendah.

Tabel 2. Hasil Refleksi Awal

\begin{tabular}{lll}
\hline Jumlah siswa & 25 orang & Keterangan \\
\hline Rata-Rata & 58.24 & Belum Tuntas \\
\hline
\end{tabular}




\begin{tabular}{ll}
\hline Daya Serap & $58.24 \%$ \\
Ketuntasan & $20.00 \%$ \\
\hline
\end{tabular}

Untuk itu peneliti berupaya mengidentifikasi permasalahan yang timbul dalam refleksi awal seperti siswa kurang termotivasi dalam mengikuti pembelajaran, hal ini terlihat dalam hasil kuisioner tentang motivasi belajar siswa ternyata masih relatif rendah

Melihat hasil refleksi awal tersebut peneliti mencoba merubah strategi pembelajaran dengan metode eksperimen dalam upaya meningkatkan prestasi dan motivasi belajar siswa pada pelajaran kimia, yang dilaksanakan melalui penelitian tindakan kelas dalam dua siklus a. Perencanaan

Berdasarkan identifikasi masalah tentang rendahnya hasil belajar dan motivasi belajar mata pelajaran kimia dan pemetaan alternatif pemecahan masalah, maka peneliti membuat dan menyiapkan hal-hal sebagai berikut :

1. Merencanakan pembelajaran yang diterapkan dalam proses belajar mengajar (PBM).

2. Menyusun pokok-pokok pembahasan dan mengembangkan skenario pembelajaran.

3. Menyusun lembar kerja siswa atau lembar kerja kelompok.

4. Menyiapkan alat dan bahan eksperimen.

5. Menyusun tes prestasi belajar dan tes motivasi belajar.

6.

b. Pelaksanaan

Penelitian dilaksanakan pada minggu II dan III bulan Maret 2019. Pada tahap ini dilaksanakan proses pembelajaran dan sekaligus pelaksanaan penelitian.

Langkah-langkah yang dilakukan sebagai berikut :

1. Apersepsi. Dengan mengajukan permasalahan atau pertanyaan yang berkaitan dengan Larutan Asam dan Basa.

2. Menyampaikan tujuan pembelajaran.

3. Membagi siswa menjadi 5 kelompok secara acak berdasarkan urutan nomor absen, dengan anggota per kelompok 5 orang.

4. Memberikan permasalahan kepada setiap kelompok dan setiap kelompok melakukan eksperimen.

5. Pelaksanaan eksperimen. Pada saat ini guru melakukan observasi terhadap kegiatan eksperimen berkaitan dengan aktivitas dan motivasi siswa dalam bereksperimen.

6. Presentasi hasil eksperimen oleh setiap kelompok dan kelompok lain mendengarkan. Presentasi dilanjutkan oleh kelompok lain sampai seluruh kelompok dapat menyampaikan hasil eksperimennya dan mendapat tanggapan dari kelompok lain.

7. Menjelang akhir pertemuan guru mengajak seluruh siswa untuk menyimpulkan materi yang telah dibahas.

8. Pada akhir kegiatan (siklus I) guru membagikan tes dan lembar kuesioner kepada siswa dan harus dijawab oleh siswa, dengan maksud untuk mengetahui sejauh mana siswa mampu menguasai dan memahami materi yang telah disajikan serta untuk mengetahui c. Observasi sejauh mana motivasi belajar siswa.

Pada tahap ini dilaksanakan observasi terhadap kegiatan belajar siswa untuk mengetahui secara langsung aktivitas belajar siswa, dan pada akhir pelaksanaan siklus, guru mengadakan evaluasi dengan menggunakan tes (lembar tes) untuk mengukur prestasi belajar siswa terhadap kompetensi dasar yang telah ditanamkan dalam proses pembelajaran serta membagikan lembar kuesioner untuk mengetahui motivasi belajar siswa. Adapun hasil tes pada akhir siklus I, dapat kami sajikan sebagai berikut :

Tabel 3. Analisis Hasil Tes Prestasi Belajar Siklus I

\begin{tabular}{lll}
\hline Jumlah Siswa & 25 orang & Keterangan \\
\hline Rata-Rata & 70,56 & Tuntas \\
Daya Serap & $70,56 \%$ & \\
\hline
\end{tabular}




Ketuntasan $64,00 \%$

Pada tahap ini dilakukan evaluasi tindakan yang telah dilakukan, meliputi evaluasi mutu, jumlah, dan waktu dari setiap jenis tindakan. Refleksi siklus bertujuan untuk memperoleh kesepakatan tindakan pada siklus berikutnya sehingga pelaksanaan tindakan berikutnya menjadi lebih baik. Berdasarkan data hasil evaluasi dan observasi kegiatan di laboratorium selama proses pembelajaran berlangsung yang dilakukan oleh siswa sendiri tetapi dengan sedikit bimbingan dari guru, maka hasil yang dicapai dalam siklus I sudah mencapai rata-rata 70.56 yakni diatas KKM, namun ketuntasan belajar baru mencapai $64.00 \%$ ini berarti masih di bawah standar ketuntasan minimal $(85.00 \%)$ dan untuk mencapai kriteria ketuntasan minimal masih perlu ditingkatkan.

Sedangkan motivasi belajar hasil kuesioner pada siklus I menunjukan bahwa kategori motivasi mencapai 9 siswa kategori cukup, 14 kategori tinggi, dan 2 orang mencapai kategori sangat tinggi, masih perlu ditingkatkan melalui siklus II.

Dari hasil pengamatan selama siklus I berlangsung dan berdasarkan hasil analisis, ada beberapa hal yang perlu mendapat penekanan, antara lain :

1. Beberapa siswa belum mampu menunjukkan aktivitas secara maksimal, ini berarti bahwa motivasi belajar siswa masih perlu ditingkatkan.

2. Beberapa kelompok belum mampu membuat suatu kesimpulan hasil diskusinya, terbukti dari presentasi hasil eksperimen masih banyak kesimpulannya perlu disempurnakan.

3. Kesiapan siswa untuk memahami konsep masih kurang, terbukti dari hasil tes yang diberikan masih banyak siswa yang kurang tepat/belum sempurna.

4. Kurang keberaniannya dalam mengemukakan pendapat dan menanggapi pertanyaan dari kelompok lain.

5. Rata-rata hasil belajar belum mencapai kriteria ketuntasan minimal (KKM).

Berdasarkan hasil analisis tersebut, maka perlu dirancang dan dilaksanakan siklus II sehingga prestasi belajar dapat ditingkatkan.

Berdasarkan hasil refleksi siklus I, maka disusun rencana pelaksanaan siklus II sebagai berikut : 1) Menyusun rencana pembelajaran, 2) Menyusun pokok-pokok materi pembahasan, 3) Menyusun lembar kerja siswa atau lembar kerja kelompok, 4) Menyiapkan alat dan bahan eksperimen, dan 5) Menyusun tes prestasi belajar dan tes motivasi belajar.

Penelitian dilaksanakan pada minggu IV bulan Maret dan minggu I bulan April 2019. Pada tahap ini dilaksanakan proses pembelajaran dan sekaligus pelaksanaan penelitian. Langkah-langkah yang dilakukan sebagai berikut :

1. Menyampaikan tujuan pembelajaran dan pokok-pokok permasalahan yang akan dieksperimenkan.

2. Membagi siswa menjadi 5 kelompok secara acak berdasarkan urutan nomor absen, dengan anggota per kelompok 5 orang. Dan memberikan permasalahan kepada setiap kelompok dan setiap kelompok melakukan eksperimen.

3. Pelaksanaan eksperimen. Pada saat ini guru melakukan observasi terhadap kegiatan eksperimen berkaitan dengan aktivitas dan motivasi siswa dalam bereksperimen sambil memberikan arahan dan bimbingan terhadap beberapa kelompok yang masih kurang mampu melaksanakan kegiatan eksperimen.

4. Presentasi hasil eksperimen oleh setiap kelompok dan kelompok lain mendengarkan. Guru menilai hasil eksperimen dan aktivitas siswa dalam presentasi. Presentasi dilanjutkan oleh kelompok lain sampai seluruh kelompok dapat menyampaikan hasil eksperimennya dan mendapat tanggapan dari kelompok lain.

5. Menjelang akhir pertemuan guru membimbing seluruh siswa untuk menyimpulkan materi yang telah dibahas.

6. Pada akhir kegiatan (siklus II) guru membagikan tes dan lembar jawaban kepada siswa dan harus dijawab oleh siswa, dengan maksud untuk mengetahui sejauh mana siswa mampu menguasai dan memahami materi yang telah disajikan.

Untuk memperoleh data tentang aktivitas serta motivasi belajar siswa maka dilakukan pengamatan secara langsung pada saat proses pembelajaran berlangsung, dan kuisioner motivasi belajar pada akhir pembelajaran. Pada akhir pelaksanaan siklus guru mengadakan 
evaluasi dengan menggunakan tes (lembar tes). Adapun hasil pengamatan dan tes akhir siklus II, dapat kami sajikan sebagai berikut :

Tabel 4. Analisis Hasil Tes Prestasi Belajar Siklus II

\begin{tabular}{lll}
\hline Jumlah Siswa & 25 Orang & Keterangan \\
\hline Rata-Rata & 80,80 & Tuntas \\
Daya Serap & $80,80 \%$ & \\
Ketuntasan & $92,00 \%$ & \\
\hline
\end{tabular}

Berdasarkan data hasil evaluasi dan observasi kegiatan di laboratorium selama proses pembelajaran berlangsung dengan metode eksperimen langsung yang dilakukan oleh siswa sendiri dan diberikan bimbingan yang lebih intensif, maka hasil yang dicapai dalam siklus II sudah mencapai rata-rata 80.80 yakni diatas $\mathrm{KKM}$, dan ketuntasan belajar baru mencapai $92.00 \%$ ini berarti sudah di atas standar ketuntasan minimal $(85.00 \%)$.

Sedangkan motivasi belajar hasil kuesioner pada siklus II menunjukan bahwa kategori motivasi mencapai 17 kategori tinggi dan 8 orang mencapai kategori sangat tinggi, berarti telah mencapai peningkatan sesuai dengan harapan.

Dari hasil analisis data pada siklus pertama dan siklus kedua pada penelitian tindakan kelas ini tentang upaya peningkatan motivasi dan prestasi belajar siswa melalui metode eksperimen pada pelajaran kimia siswa kelas X Teknik Otomotif 4 di SMK Negeri 2 Negara Tahun Pelajaran 2018/2019, dapat dikatakan bahwa terdapat peningkatan yang signifikan dimana dari data refleksi awal rata-rata prestasi belajar, daya serap, dan ketuntasan klasikal relatif rendah, namun setelah dilaksanakan siklus pertama dan siklus kedua dengan model pembelajaran eksperimen pada pelajaran kimia siswa kelas X Teknik Otomotif 4 di SMK Negeri 2 Negara, hasilnya meningkat secara umum dimana prestasi belajar mencapai rata-rata 80.80 , dan ketuntasan belajar mencapai $92.00 \%$, telah meningkat secara signifikan dari hasil sebelumnya. Adapun peningkatannya dapat dilihat dalam tabel berikut ini:

Tabel 5. Rata-Rata, Daya Serap, dan Ketuntasan Belajar

\begin{tabular}{lllllll}
\hline \multirow{2}{*}{ Siklus } & \multicolumn{2}{l}{ Rata-Rata } & \multicolumn{2}{c}{ Daya Serap } & \multicolumn{2}{l}{ Ketuntasan Belajar } \\
& Nilai & Peningkatan & Besar & Peningkatan & Besar & Peningkatan \\
\hline Pra & 58.24 & & $58.24 \%$ & & $20.00 \%$ & \\
I & 70.56 & 12.32 & $70.56 \%$ & $12.32 \%$ & $64.00 \%$ & $44.00 \%$ \\
II & 80.80 & 10.24 & $80.80 \%$ & $10.24 \%$ & $92.00 \%$ & $28.00 \%$ \\
\multicolumn{2}{l}{ Total Peningkatan } & 22.56 & $22.56 \%$ & & $72.00 \%$ & \\
\hline
\end{tabular}

Dari Tabel di atas dapat dijelaskan bahwa peningkatan rata-rata prestasi belajar sebesar $22.56(80.80-58.24=22.56)$ dan ketuntasan belajar mencapai peningkatan sebesar $72.00 \%$ $(92.00 \%-20.00 \%=72.00 \%)$ dari prestasi belajar sebelum dilaksanakan metode eksperiman dibandingkan dengan telah dilaksanakannya metode eksperimen. Ini berarti terdapat peningkatan yang sangat signifikan

Sedangkan hasil observasi terhadap motivasi belajar siswa pada saat refleksi awal menunjukan masih rendahnya motivasi belajar dimana siswa yang memiliki katagori rendah 7 orang, siswa yang memiliki motivasi kategori cukup 15 orang, dan siswa yang memiliki kategori tinggi 3 orang. Ternyata setelah dilaksanakan siklus pertama dan kedua dengan disertai beberapa alternatif perbaikan pelaksanaan dalam siklus tersebut, menunjukan adanya peningkatan motivasi belajar yang sangat signifikan, dimana siswa yang memiliki motivasi tinggi sebanyak 17 orang dan memiliki motivasi sangat tinggi sebanyak 8 orang.

\section{Simpulan dan Saran}

Berdasarkan Berdasarkan deskripsi hasil analisis data, dan pembahasan hasil penelitian, maka dapat disimpulkan hasil penelitian sebagai berikut : 
1. Bahwa pembelajaran dengan metode eksperimen dapat meningkatkan motivasi belajar kimia siswa kelas X Teknik Otomotif 4 SMK Negeri 2 Negara tahun pelajaran 2018/2019.

2. Bahwa pembelajaran dengan metode eksperimen dapat meningkatkan prestasi belajar kimia siswa kelas X Teknik Otomotif 4 SMK Negeri 2 Negara tahun pelajaran 2018/2019.

Berdasarkan simpulan hasil penelitian dan pembahasan tersebut di atas, maka kami sampaikan saran sebagai berikut :

1. Pada proses belajar mengajar di kelas atau di laboratorium guru harus selalu berinteraksi dengan siswa, karena dengan komunikasi yang baik dapat terjadi timbal balik antara guru dengan siswa. Siswa bisa lebih terbuka kepada guru ketika menghadapi kesulitan dalam proses belajar mengajar sehingga siswa dapat lebih aktif selama pembelajaran berlangsung.

2. Kepada guru mata pelajaran kimia senantiasa berupaya menggunakan metode pembelajaran yang mampu meningkatkan prestasi belajar siswa dan motivasi belajar siswa dalam proses pembelajaran, salah satu diantaranya menggunakan metode eksperimen. Hal ini sesuai dengan penelitian ini yang menunjukkan bahwa penggunaan metode eksperimen terbukti memberikan pengaruh yang signifikan terhadap peningkatan motivasi dan prestasi belajar siswa.

3. Kepada lembaga terkait, khususnya lembaga pendidikan agar mendorong dan memotivasi guru untuk senantiasa meningkatkan kemampuan profesionalnya, sehingga kualitas proses pembelajaran dapat ditingkatkan serta prestasi belajar siswa dapat ditingkatkan.

\section{Daftar Pustaka}

Bungin, Burhan, 2013. Metode Penelitian Sosial dan Ekonomi : Format-Format Kuantitatif dan Kualitatif untuk Studi Sosiologi, Kebijakan, Publik, Komunikasi, Manajemen, dan Pemasaran Edisi Pertama. Jakarta: Kencana Prenada Media Group.

Depdiknas, 2005. Peraturan Pemerintah Republik Indonesia Nomor 19 Tahun 2005 tentang Standar Nasional Pendidikan, Jakarta: Mendiknas.

Dimyati dan Mudjiono, 2006. Belajar dan Pembelajaran, Jakarta: PT. Rineka Cipta.

Djamarah, S.B., 2004. Prestasi Belajar dan Kompetensi Guru. Surabaya: Usaha Nasional.

Hopkins, David, 2011. Panduan Guru Penelitian Tindakan Kelas (A Teacher's Guide To Classroom Research). Yogyakarta: Pustaka Pelajar.

Indrawati, 2009. Model Pembelajaran Terpadu di Sekolah Dasar Untuk Guru SD. Jakarta. Penerbit Pusat Pengembangan dan Pemberdayaan Pendidik dan Tenaga Kependidikan IImu Pengetahuan Alam (PPPPTK IPA) untuk Program Bermutu.

Mbulu Joseph, 2001. Pendekatan dan Bentuk Pengajaran Individual, Malang: Jurusan TEF FIP UM.

Nurkancana, Wayan dan Sunartana, 2006. Evaluasi Hasil Belajar. Surabaya: Usaha Nasional.

Nasution, M.A., 2009. Berbagai Pendekatan dalam Proses Belajar Mengajar. Jakarta: PT. Bumi Aksara.

Noor, Juliansyah, 2011. “Metode Penelitian: Skripsi, Tesis, Disertasi, dan Karya IImiah”. Jakarta : Kencana Prenada Media Group.

Padmanaba, I. K. G., Kirna, I. M., \& Sudria, I. N. (2018). Pengembangan Media Pembelajaran Interaktif Kimia Koloid Berbantuan Komputer Untuk Siswa SMA. Jurnal Pendidikan Kimia Indonesia, 2(1), 15-24. 
Prayitno, 2004. Buku Seri Bimbingan dan Konseling Layanan Bimbingan dan Konseling Kelompok (Dasar dan Profil). Jakarta: Ghalia Indonesia.

Purwanto, Ngalim, 2009. Evaluasi Hasil Belajar. Yogyakarta: Pustaka Pelajar.

Roestiyah, N.K., 2008. Strategi Belajar Mengajar. Jakarta: PT. Rineka Cipta.

Sardiman, A.M., 2007. Interaksi dan Motivasi Belajar Mengajar, Jakarta: PT. Raja Grafindo Persada.

Slameto, 2003. Belajar dan Faktor yang Mempengaruhi. Jakarta: Rineka Cipta.

Sudjimat, Dwi Agus, 2004. Metodologi Penelitian. Surabaya: Universitas PGRI Adibuana Surabaya.

Suhardjono dan Rufi'l, 2006. Metodologi Penelitian. Surabaya: Program Pascasarjana UNIPA.

Suharsimi Arikunto, 2004. Evaluasi Program Pendidikan, Jakarta: Bumi Aksara.

Sutopo, 2006. Metodologi Penelitian Kualitatif. Surakarta: UNS.

Sugiyono, 2008. Metode Penelitian Kuantitatif Kualitatif dan $R \& D$. Bandung: Alfabeta.

Trianto, 2007. Pembelajaran Inovatif Berorientasi Konstruktivistik, Jakarta: Prestasi Pustaka. 